\title{
Pembelajaran Online pada Masa Pandemi Covid-19 Meningkatkan Kesulitan Belajar Matematika pada Siswa Sekolah Dasar
}

\author{
Siti Annisah ${ }^{1}$, Siti Masfi'ah ${ }^{2}$ \\ ${ }^{1}$ Prodi Pendidikan Guru Madrasah Ibtidaiyah, Fakultas Tarbiyah dan Ilmu Keguruan, IAIN Metro, \\ Lampung, Indonesia \\ ${ }^{2}$ Madrasah Ibtidaiyah Negeri (MIN) 4 Lampung Timur, Lampung, Indonesia \\ *Email: sitiannisah80@gmail.com
}

\begin{abstract}
Abstrak
Pembelajaran online di masa pandemic covid-19 membuat siswa SD semakin sulit menguasai materi matematika. Tujuan penelitian ini adalah mendeskripsikan bagaimana pembelajaran online telah meningkatkan kesulitan belajar matematika bagi siswa sekolah dasar. Penelitian ini dilakukan secara deskriptif kualitatif yang melibatkan 31 siswa, 9 orangtua, dan guru kelas IV MIN 4 Lampung Timur. Wawancara dan dokumentasi digunakan untuk mendapatkan data primer dan sekunder. Analisis data dilakukan melalui tiga tahapan yaitu reduks, display, dan verifikasi data. Temuan penelitian ini adalah 1) terjadi penurunan hasil belajar matematika pada siswa sekolah dasar sebagai akibat pembelajaran online, 2) peningkatan kesulitan belajar matematika yang dialami siswa pada pembelajaran online, dan 3) aspek-aspek yang menjadi penyebab meningkatnya kesulitan belajar matematika pada pembelajaran online. Dengan demikian pembelajaran online di awal masa pendemi covid-19 memberi dampak negative terhadap peningkatan kesulitan belajar matematika bagi siswa sekolah dasar.
\end{abstract}

Kata kunci: Kesulitan Belajar Matematika, Pembelajaran Online, Pemahaman Konsep, Pendampingan Belajar.

Abstract

Online learning during the Covid-19 pandemic made elementary students even more difficult to master math material. The purpose of this study was to describe how online learning can increase the difficulty of learning mathematics for elementary school students. This research was conducted in a descriptive qualitative manner involving 31 students, 9 parents, and class IV teachers of MIN 4 East Lampung. Interviews and documentation are used to obtain primary and secondary data. Data analysis was carried out in three stages, namely reduction, display, and data verification. The findings of this study are 1) there has been a decrease in mathematics learning outcomes in elementary school students as a result of online learning, 2) an increase in mathematics learning difficulties experienced by students in online learning, and 3) aspects that cause an increase in mathematics learning difficulties in online learning. Thus online learning at the beginning of the Covid-19 epidemic had a negative impact on increasing math learning difficulties for elementary school students.

Keywords: Mathematics Learning Difficulties, Online Learning, Concept Understanding, Learning Assistance.

\section{PENDAHULUAN}

Pembelajaran online yang telah dilaksanakan selama masa pandemic COVID19 semakin menambah kesulitan bagi siswa ketika belajar matematika. Pengusaan konsep dan prosedur matematika bagi siswa terutama siswa SD dipengaruhi oleh kemampuan prasyarat siswa dan pendampingan guru atau orangtua dalam proses pembelajaran.
Kemampuan prasyarat siswa menjadi penentu dalam penguasaan konsep matematika. Begitu pula pendampingan dalam belajar telah menjadi faktor keberhasilan dalam pendidikan online. Sementara itu siswa dengan kemampuan prasyarat yang kurang dan tanpa pendamping belajar tidak mampu menguasai konsep dan prosedur matematika yang bersifat abstrak. 
Prestasi siswa tidak hanya dipengaruhi oleh penggunaan media pembelajaran online tetapi oleh kesiapan siswa dan pendampingan guru atau orangtua dalam melakukan aktivitas belajar. Perubahan tradisi pendidikan berbasis teknologi menyebabkan pendidikan tidak lagi memberikan kemudahan bagi siswa untuk mencapai kompetensi yang diharapkan sebagaimana yang selama ini terjadi. Pandemi telah mengubah pendidikan menjadi proses yang semakin mempersulit siswa ketika belajar matematika. Pendidikan online yang seharusnya menjadi jalan membantu siswa justru telah mempersulit siswa terutama bagi siswa SD untuk memahami konsep matematika yang abstrak.

Sejauh ini studi tentang hubungan pembelajaran online dengan kesulitan belajar matematika dapat dikelompokkan menjadi pada tiga tipe penelitian. Pertama, studi hubungan pandemic dengan pembelajaran yang mengidentifikasi pada letak kesulitan yang dialami siswa baik dalam menguasai konsep matematika maupun secara teknis (Annur and Hermansyah, 2020; (Faznur et al., 2020); Anugrahana, 2021). Kedua, studi yang menjelaskan faktor internal seperti motivasi dan eksternal seperti ekonomi keluarga yang mempengaruhi keberhasilan siswa dalam pembelajaran online (Winarti, 2021). Ketiga, studi yang mengevaluasi pelaksanaan pembelajaran online, termasuk capaian siswa dalam pembelajaran (Loviana and Baskara, 2019; Hadiprasetyo, Exacta and Maharani, 2020; Mustakim, 2020; Yulia and Putra, 2020; Zamista et al., 2020). Kecenderungan studi tersebut melihat pendidikan sebagai proses hubungan peserta didik dalam mencapai tujuan pendidikan, mengabaikan fungsi pendidikan sebagai sarana yang membantu peserta didik untuk mengembangkan semua potensi yang dimilikinya secara maksimal.

Studi ini dilakukan untuk melengkapi kekurangan dari studi terdahulu tentang hubungan pembelajaran online dengan kesulitan belajar matematika yang dialami oleh siswa dengan cara menganalisis bagaimana pembelajaran pada masa pandemic COVID-19 telah menambah pemasalahan bagi siswa dalam menguasai capaian pembelajaran matematika. Oleh karena itu, dua pertanyaan dijawab dalam penelitian ini: (a) bagaimana proses pembelajaran berlangsung dan dijalani oleh siswa pada masa pandemic, dan (b) bagaimana kesulitan belajar itu terjadi pada pembelajaran online (membedakan siswa berdasarkan yang mendapat pendampingan belajar dan tidak., kesiapan siswa belajar mandiri). Kedua pertanyaan tersebut memberikan pemahaman bahwa keberhasilan pembelajaran di masa pandemic tidak hanya ditentukan oleh terpenuhinya kebutuhan gadget, internet, dan media pembelajaran lainnya tetapi juga pendampingan belajar terutama bagi siswa SD yang dapat membantu mereka ketika menghadapi kesulitan belajar dan mengembangkan potensi yang dimiliki secara maksimal. Pendampingan belajar bagi siswa SD telah menentukan keberhasilan proses pendidikan.

Penelitian ini disandarkan pada suatu argument bahwa kesulitan belajar matematika selama masa pandemic telah memberi pengaruh langsung bagi siswa dalam menguasai materi 
dan pencapaian kompetensi siswa yang menjadi tujuan pembelajaran. Penggunaan teknologi tanpa pendampingan orangtua / guru mempengaruhi meningkatnya kesulitan siswa dalam proses belajar. Siswa yang menggunakan teknologi tanpa pendampingan guru/orangtua tidak mampu memanfaatkan sumber-sumber belajar dengan baik dan cenderung melakukan aktivitas lain selain kegiatan belajar. Kesulitan belajar siswa yang dipengaruhi oleh kemampuan prasyarat dan pendampingan belajar telah menjadi dasar bagi prestasi siswa dalam pendidikan. Ketika pendampingan belajar menjadi syarat bagi prestasi siswa maka siswa yang tidak didampingi guru ketika proses belajar akan mendapatkan hasil evaluasi belajar yang lebih rendah dibandingkan siswa dari kelompok yang lebih beruntung.

\section{METODE PENELITIAN}

Penelitian ini merupakan penelitian deskriptif kualitatif yang bersandar pada data primer dan sekunder. Data primer terdiri dari proses pembelajaran yang berlangsung, kesiapan siswa belajar mandiri, bagaimana kesulitan siswa terjadi dalam pembelajaran. Data sekunder terdiri dari hasil belajar matematika, latar belakang keluarga siswa. Kedua jenis data tersebut digunakan sebagai dasar melakukan analisis hubungan antara pembelajaran online dengan kesulitan belajar matematika.

Penelitian ini melibatkan siswa sebanyak 31 siswa, sembilan orang tua dan guru kelas VI MIN 4 Lampung Timur pada tahun 2020. Teknik pengumpulan data menggunakan wawancara dan dokumentasi. Wawancara dilakukan kepada siswa dan orangtua yang menerima akibat langsung dari pembelajaran online. Dokumentasi digunakan untuk mendapatkan data hasil belajar, profil siswa dan orangtua siswa. Baik data primer maupun sekunder menjadi landasan dalam menganalisis hubungan pembelajaran online dengan peningkatan kesulitan belajar.

Analisis data dilakukan melalui tiga tahapan. Pertama, reduksi data sebagai proses penataan data dalam bentuk yang lebih sistematis. Kedua, display data sebagai upaya mewujudkan data dalam bentuk tabel. Ketiga, verifikasi data sebaagai suatu tahapan penyimpulan data. Data penelitian yang diproses melalui tiga tahap tersebut dianalisis melalui metode deskriptif dan content analysis. Tahapan dan teknik analisis tersebut digunakan untuk merumuskan kesimpulan atas hubungan pembelajaran online dengan kesulitan belajar siswa.

\section{HASIL PENELITIAN}

Hasil penelitian ini diuraikan menjadi dua temuan yaitu 1) data hasil belajar sebelum dan pada saat pandemic, dan 2) pembelajaran online mempengaruhi terjadinya kesulitan belajar siswa (proses pembelajaran online yang berlangsung dan terjadinya kesulitan belajar dalam pembelajaran online)

\section{Data hasil belajar matematika sebelum dan pada saat pandemi Covid-19}

Hasil belajar matematika sebelum dan selama pandemi Covid-19 diperoleh dari data hasil penilaian di semester ganjil (sebelum pandemi) dan semester genap (pada saat pandemi). Berikut ini disajikan data hasil 
belajar matematika siswa kelas IV MIN 4 Lampung Timur TP. 2019/2020.

Tabel 1. Data Hasil Belajar Matematika Sebelum dan Selama Pandemi Covid-19

\begin{tabular}{ccccccc}
\hline \multirow{2}{*}{ No } & \multirow{2}{*}{$\begin{array}{c}\text { Data Hasil Belajar } \\
\text { Matematika }\end{array}$} & $\begin{array}{c}\text { Rata- } \\
\text { rata }\end{array}$ & $\begin{array}{c}\text { Jumlah siswa } \\
\text { yang Tuntas }\end{array}$ & $\begin{array}{c}\text { Jumlah siswa yang } \\
\text { Tidak Tuntas }\end{array}$ & $\begin{array}{c}\text { Tuntas } \\
\text { Tundak }\end{array}$ & $\begin{array}{c}\text { Tidak } \\
\text { Tuntas }\end{array}$ \\
\hline 1 & Sebelum Pandemi Covid-19 & 73 & 18 & 13 & $58 \%$ & $42 \%$ \\
\hline 2 & Selama Pandemi Covid-19 & 59 & 12 & 19 & $39 \%$ & $61 \%$ \\
\hline
\end{tabular}

Pada Tabel 1 dapat dilihat bahwa tingkat ketuntasan dan rata-rata hasil belajar matematika siswa sebelum masa pendemi lebih tinggi daripada pada saat pandemi. Dari data tersebut menunjukkan bahwa pembelajaran tatap muka dapat mengembangkan kompetensi siswa lebih baik daripada pembelajaran online pada masa pandemi.

\section{Pembelajaran online mempengaruhi peningkatan kesulitan belajar siswa}

Peningkatan kesulitan belajar siswa selama pembelajaran online dapat dijelaskan menjadi enam aspek yaitu 1) proses pembelajaran online yang dilaksanakan, 2) kemampuan memahami materi atau prosedur matematika, 3) ketersediaan media pembelajaran yang diperlukan selama pandemic covid-19, 4) pemanfaatan teknologi, media online, aplikasi belajar, dan internet, 5) pendampingan belajar siswa, dan 6) solusi yang ditempuh guru, siswa, dan orangtua atas setiap kesulitan. Berdasarkan hasil wawancara dengan guru, siswa, dan orangtua siswa diperoleh informasi berikut ini:

Tabel 2. Deskripsi Kesulitan Belajar Matematika pada Pembelajaran Online selama Masa Pandemi Semester Genap TP. 2019/2020

\begin{tabular}{|c|c|c|}
\hline No & Aspek & Deskripsi \\
\hline 1 & $\begin{array}{l}\text { Proses pembelajaran online } \\
\text { yang berlangsung }\end{array}$ & $\begin{array}{l}\text { Pembelajaran online dilakukan di MIN } 4 \text { Lampung Timur dengan } \\
\text { menggunakan aplikasi whatsapp. Aplikasi whatsapp digunakan untuk } \\
\text { melakukan komunikasi antara guru, siswa, dan orangtua, serta } \\
\text { mengirimkan materi (materi ajar, lembar kerja, video pembelajaran, } \\
\text { lembar penilaian) }\end{array}$ \\
\hline \multirow[t]{3}{*}{2} & $\begin{array}{l}\text { Kemampuan memahami } \\
\text { materi atau prosedur } \\
\text { matematika }\end{array}$ & $\begin{array}{l}\text { a. Banyak siswa yang kesulitan dalam memahami konsep atau prosedur } \\
\text { matematika, terutama siswa yang memiliki kemampuan matematika } \\
\text { cukup dan kurang baik. }\end{array}$ \\
\hline & & $\begin{array}{l}\text { b. Tingkat kesalahan siswa dalam menyelesaikan soal matematika } \\
\text { semakin tinggi }\end{array}$ \\
\hline & & $\begin{array}{l}\text { c. Siswa yang memiliki kemampuan matematika sangat baik dapat } \\
\text { mengikuti pembelajaran online dan mampu memahami materi serta } \\
\text { menyelesaikan soal dengan baik. }\end{array}$ \\
\hline 3 & $\begin{array}{l}\text { Ketersediaan media } \\
\text { pembelajaran yang } \\
\text { diperlukan selama pandemic } \\
\text { covid-19 }\end{array}$ & $\begin{array}{l}\text { Sebanyak } 98 \% \text { siswa atau orangtua siswa memiliki media HP untuk } \\
\text { digunakan dalam pembelajaran online }\end{array}$ \\
\hline \multirow[t]{2}{*}{4} & $\begin{array}{l}\text { Pemanfaatan teknologi, } \\
\text { media online, aplikasi } \\
\text { belajar, dan internet }\end{array}$ & $\begin{array}{l}\text { a. Hampir seluruh siswa atau orangtua siswa memiliki handphone untuk } \\
\text { digunakan pada pembelajaran online. Namun kemampuan untuk } \\
\text { menggunakan dan memanfaatkan aplikasi dan media belajar online } \\
\text { belum maksimal. }\end{array}$ \\
\hline & & dan kuota internet yang terbatas \\
\hline
\end{tabular}


5 Pendampingan belajar siswa a. Pendampingan belajar yang dilakukan orangtua kepada anakanaknya. Ada 3 tipe yaitu (a) tipe orangtua yang bisa dan mampu mendampingi anak belajar tetapi terkendala anak mudah bosan, (b) tipe orangtua yang bisa mendampingi anak belajar, tetapi tidak mampu membantu menjelaskan materi matematika kepada anaknya, (c) (c) tipe orangtua yang tidak bisa mendampingi anak belajar karena kesibukan

b. Siswa yang cenderung memperoleh dampingan belajar selama pembelajaran online memiliki kemampuan dan hasil belajar yang lebih baik daripada siswa yang tidak atau kurang mendapat pendampingan belajar.

6 Solusi yang ditempuh guru, a. Waktu pembelajaran online yang disediakan mulai pagi sampai siswa, dan orangtua atas setiap kesulitan malam hari. Hal ini untuk memberi kesempatan kepada orangtua yang bekerja di pagi, siang, atau sore hari.

b. Guru memberikan video pembelajaran kepada siswa untuk membantu siswa memahami materi dan untuk mengurangi kebosanan siswa.

Pada Tabel 2 dapat mendekripsikan bagaimana pembelajaran online yang terapkan mempengaruhi peningkatan kesulitan belajar matematika. Pertama, pelaksanaan pembelajaran online yang dilakukan belum menggunakan aplikasi yang bervariasi, karena hanya menggunakan aplikasi whatsapp. Penggunaan aplikasi tersebut kurang dapat menfasilitasi keterlibatan siswa secara aktif pada proses pembelajaran, karena kepemilikan handphone lebih banyak dimiliki oleh orangtua, sehingga siswa dapat belajar jika orangtuanya sedang tidak bekerja atau dipinjamkan oleh orangtua. Dengan demikian, dari aspek proses pembelajaran online yang dilaksanakan pada saat pandemi covid-19 belum dapat mendorong siswa terlibat aktif dalam pembelajaran.

Kedua, kemampuan siswa dalam memahami materi atau prosedur matematika serta menyelesaikan soal matematika belum baik. Semakin banyak kesalahan yang dilakukan siswa ketika menyelesaikan soal menunjukkan bahwa pembelajaran online yang dilaksanakan semakin menambah kendala siswa dalam menguasai materi matematika.
Terutama bagi siswa yang memiliki kemampuan sedang dan kurang baik semakin sulit memahami materi. Namun, bagi siswa yang memiliki kemampuan kategori sangat baik dapat mengikuti dan menguasai materi dengan baik. Peningkatan kesalahan yang dilakukan siswa tersebut merupakan dampak pembelajaran online yang telah dilaksanakan.

Ketiga, terkait ketersediaan media pembelajaran menunjukkan bahwa hampir semua siswa memiliki atau dapat menggunakan handphone orangtuanya untuk kegiatan belajar. Kondisi tersebut menjadi faktor yang mendukung keberhasilan pembelajaran online.

Keempat, pemanfatan teknologi dan media online dalam pembelajaran. Penggunaan teknologi untuk kegiatan belajar belum dilakukan secara maksimal. Dari hasil wawancara dengan orangtua siswa menjelaskan bahwa kepemilikan handphone lebih banyak digunakan untuk kegiatan bermain game dan medsos daripada untuk aktivitas belajar. 
Kelima, pendampingan belajar bagi siswa selama pembelajaran online sangat penting. Siswa yang memperoleh dampingan belajar selama pembelajaran online memiliki kemampuan dan hasil belajar yang lebih baik daripada siswa yang tidak atau kurang mendapat pendampingan belajar. Kesibukan dan kemampuan orangtua sangat mempengaruhi kualitas bimbingan belajar anak.

Keenam, solusi yang ditempuh oleh guru dan orangtua ketika terjadi kendala dalam proses pembelajaran dilakukan berdasarkan diskusi dan komunikasi antara guru, siswa dan orangtua. Beberapa solusi tersebut antara lain waktu beajar online diperpanjang mulai pagi sampai malam hari, dan pemberian video pembelajaran yang bervariasi dan menarik untuk membantu siswa menguasai materi dan mengurangi kebosanan ketika belajar.

\section{PEMBAHASAN}

Berdasarkan hasil penelitian yang telah diuraikan menunjukkan bahwa temuan penelitian ini meliputi 1) terjadi penurunan hasil belajar matematika pada siswa sekolah dasar akibat pembelajaran online, 2) terjadinya peningkatan kesulitan belajar matematika yang dialami siswa pada pembelajaran online, dan 3) aspek-aspek yang menjadi penyebab meningkatnya kesulitan belajar matematika pada pembelajaran online.

Pertama, penurunan kemampuan matematika yang dimiliki siswa terjadi pada saat pembelajaran online. Penurunan kemampuan tersebut dapat dilihat dari ratarata hasil belajar matematika akibat pembelajaran online yang dilaksanakan pada masa pendemi lebih rendah daripada rata-rata hasil belajar matematika sebelum pandemic covid-19. Banyaknya kesalahan yang dilakukan siswa dalam menyelesaikan soal matematika mengindikasikan bahwa masih banyak siswa yang mengalami kesulitan dalam memahami materi matematika. Hal ini sesuai dengan hasil penelitian yang menyebutkan bahwa salah satu dampak negatif dari pembelajaran online di masa pandemic covid19 adalah pemahaman siswa terhadap materi kurang optimal (Loviana and Baskara, 2019). Dengan demikian, pembelajaran online yang dilaksanakan pada masa pandemic covid 19 menyebabkan terjadinya penurunan kemampuan matematika pada siswa. Melemahnya kemampuan tersebut berkorelasi dengan meningkatnya kesulitan belajar pada siswa.

Kedua, peningkatan kesulitan belajar matematika pada siswa terjadi pada pembelajaran online di masa pandemic covid19. Kesulitan belajar matematika yang dialami oleh siswa tersebut dapat dijelaskan melalui beberapa aspek, yaitu 1) sulit memahami dan menyelesaikan soal matematika, 2) sulit berkonsentrasi dan mudah bosan melakukan aktivitas belajar matematika, 3) sulit menggunakan atau memanfaatkan teknologi untuk kegiatan belajar.

Kesulitan siswa dalam memahami dan menyelesaikan soal dapat terlihat dari banyaknya kesalahan pada jawaban yang dikerjakan oleh siswa. Hal ini sesuai dengan hasil penelitian sebelumnya yang menyatakan bahwa ketidakmampuan siswa dalam 
membaca, memahami masalah, dan menggunakan pengetahuan dalam menyelesaikan masalah berkaitan dengan kesulitan belajar matematika (Anugrahana, 2021). Selain itu, konsep materi matematika yang bersifat abstrak harus dikuasai oleh siswa sekolah dasar yang masih berpikir konkrit menjadi sesuatu yang berat untuk dicapai.

Kesulitan siswa berkonsentrasi ketika belajar dan cepat merasa bosan melakukan aktivitas belajar matematika selama pembelajaran online dialami oleh sebagian besar siswa MIN 4 Lampung Timur. Pembelajaran online selama masa pandemic covid-19 mengharuskan semua kegiatan belajar dilakukan di rumah. Perubahan suasana belajar yang semula di sekolah dan sekarang harus di rumah, interaksi dengan guru dan teman-teman yang terbatas, pendampingan belajar anak oleh orangtua yang kurang optimal menyebabkan anak kurang focus belajar, motivasi belajar menurun, dan cepat bosan dalam melakukan kegiatan pembelajaran. Hal ini sesuai dengan hasil penelitian yang menjelaskan bahwa siswa tidak antusias dalam mengikuti pembelajaran daring (Hadiprasetyo, Exacta and Maharani, 2020), motivasi belajar siswa semakin menurun ketika mengikuti pembelajaran online (Cahyani et al., 2020).

Selanjutnya kesulitan menggunakan atau memanfaatkan gadget dalam pembelajaran online juga dialami oleh sebagian besar siswa. Secara umum dari aspek kepemilikan handphone atau gadget untuk menunjang kegiatan pembelajaran online terpenuhi. Hampir semua orangtua siswa memiliki gadget yang dapat dimanfaatkan dalam pembelajaran daring. Namun, dari aspek kemampuan menggunakan gadget untuk pembelajaran online mengalami banyak kendala. Hal itu dialami oleh guru, orangtua, dan siswa. Penerapan pembelajaran online yang secara tiba-tiba di awal masa pandemic Covid-19 telah memaksa dan tidak memberi kesempatan kepada guru, siswa dan orangtua untuk menyiapkan diri menggunakan teknologi dan berbagai aplikasi belajar sebagai media utama yang digunakan dalam pembelajaran online. Ketidaksiapan tersebut menyebabkan penggunaan dan pemanfaatan gadget untuk kegiatan belajar kurang optimal, sehingga mempengaruhi capaian hasil belajar matematika.

$$
\text { Ketiga, faktor-faktor yang }
$$
mempengaruhi peningkatan kesulitan belajar matematika selama pembelajaran online dijelaskan menjadi tiga hal yaitu 1) proses pelaksanaan pembelajaran online, 2) kemampuan memanfaatkan teknologi, media online, aplikasi belajar, internet, dan 3) pendampingan belajar.

Proses pembelajaran online selama masa pandemic sangat mempengaruhi keberhasilan capaian pembelajaran. Peningkatan kesulitan belajar matematika yang dialami oleh siswa berbanding lurus dengan rendahnya hasil belajar matematika pada pembelajaran online. Hal tersebut dapat dipahami bahwa pada pembelajaran online, siswa diharuskan belajar secara mandiri di rumah tanpa adanya sosok guru yang selama ini siap membimbing mereka secara langsung. 
Pada sisi lain, usia anak sekolah dasar masih membutuhkan pendampingan dan bimbingan belajar lebih intensif. Tanpa sosok guru yang membimbing belajar secara langsung membuat siswa bingung dan kesulitan dalam melakukan aktivitas belajar.

Selanjutnya, kemampuan memanfaatkan teknologi, media online, aplikasi belajar, dan internet juga mempengaruhi peningkatan kesulitan belajar siswa. Saat ini, kemajuan teknologi telah menyediakan berbagai media dan aplikasi belajar online yang siap digunakan untuk memudahkan setiap orang melakukan kegiatan belajar. Namun pada kenyataannya, masih banyak guru, siswa, dan orangtua siswa belum mampu memanfaatkan teknologi secara maksimal. Seperti yang terjadi di MIN 4 Lampung Timur, pembelajaran online yang telah dilaksanakan di awal masa pademi covid-19 hanya menggunakan aplikasi whatsapp saja. Aplikasi whatsapp digunakan oleh guru untuk mengirimkan materi dan memberikan tugas. Akibatnya, siswa dan orangtua hanya menerima informasi dan tugas yang dikirim oleh guru. Kalaupun ada komunikasi biasanya berkaitan dengan teknis pembelajaran. Beberapa hasil penelitian menyebutkan bahwa salah satu kesulitan belajar yang sering terjadi pada pembelajaran online adalah siswa hanya menunggu instruksi atau tugas guru, belum mempunyai inisiatif untuk belajar sendiri (Yulia and Putra, 2020).

Faktor selanjutnya adalah pendampingan belajar bagi siswa sekolah dasar menjadi sesuatu yang sangat penting. Ada beberapa alasan mengapa pendampingan belajar sangat dibutuhkan siswa sekolah dasar. Pertama, dari aspek usia, siswa SD belum mampu belajar secara mandiri karena masih membutuhkan bantuan dan bimbingan dari guru. Sementara pada pembelajaran online tidak ada sosok guru secara fisik hadir dalam kegiatan belajar. Oleh karena itu, orangtua menjadi sosok yang harus berperan sebagai guru yang dapat membantu dan membimbing anaknya belajar di rumah. Kedua, materi matematika yang bersifat abstrak menjadi sesuatu yang sulit untuk dikuasai oleh siswa sekolah dasar. Penggunaan media pembelajaran atau alat peraga konkrit dibutuhkan siswa untuk menjadi jembatan memahami sesuatu yang abstrak. Hal bisa terjadi jika ada orangtua/pembimbing yang membantu menghadirkan alat peraga tersebut dalam proses pembelajaran. Dengan demikian, orangtua memiliki peran yang sangat penting bagi anak SD dalam pembelajaran online. Hal ini sesuai hasil penelitian sebelumnya yang menyebutkan bahwa orangtua memiliki peran sentral dalam mendidik anak terutama pada pembelajaran online (Trisnawati, 2021).

Berkaitan dengan pendampingan belajar, penelitian ini memiliki temuan tambahan yaitu bahwa ternyata siswa yang ketika belajar secara online mendapat pendampingan belajar dari orangtuanya mempunyai motivasi dan kemampuan matematika yang lebih baik daripada siswa yang tidak atau kurang pendampingan belajar. Hal ini diperkuat oleh hasil penelitian sebelumnya bahwa keterlibatan orangtua dalam mendampingi anak belajar sangat berpengaruh atas keberhasilan anak, 
membantu anak dalam mengembangkan kompetensi, motivasi, dan prestasi anak (Menheere and Hooge, 2016). Dengan demikian, keterlibatan orangtua dalam mendampingi anak belajar selama pembelajaran online dapat membantu mengatasi kesulitan belajar yang dialami oleh anak. Hal itu dapat berimplikasi kepada peningkatan kemampuan atau hasil belajar matematika.

\section{SIMPULAN}

Ternyata pembelajaran online di awal masa pendemi covid-19 memberi dampak negatif yakni meningkatkan kesulitan belajar matematika bagi siswa sekolah dasar. Temuan penelitian ini menekankan bahwa kesulitan belajar matematika selama pembelajaran online tidak hanya berkaitan dengan kepemilikan gadget, sinyal internet, tetapi kesulitan memahami materi matematika yang bersifat abstrak, sulit untuk belajar mandiri sehingga susah konsentrasi dan mudah bosan melakukan aktivitas belajar matematika, dan sulit menggunakan atau memanfaatkan teknologi untuk kegiatan belajar. Selanjutnya penelitian ini juga menjelaskan kesulitan belajar matematika tersebut dapat diminimalisir dengan melakukan pendampingan belajar siswa SD secara maksimal.

Penelitian ini memiliki beberapa keterbatasan, diantaranya 1) penelitian ini hanya dilakukan pada satu kelas di Lampung Timur, 2) penelitian ini dilakukan di awal masa pandemic covid-19 yaitu semester genap
2019/2020 sehingga kesiapan guru dan siswa masih kurang dalam pembelajaran daring.

\section{DAFTAR PUSTAKA}

Annur MF, Hermansyah. 2020. Analisis Kesulitan Mahasiswa Pendidikan Matematika Dalam Pembelajaran Daring Pada Masa Pandemi Covid-19. Paedagoria: Jurnal Kajian, Penelitian dan Pengembangan Kependidikan, 11(2): 195-201.

Anugrahana A. 2021. Analisis Kemampuan Pemahaman Kognitif Dan Kesulitan Belajar Matematika Konsep " Logika ” Dengan Model Pembelajaran Daring. Scholaria: Jurnal Pendidikan dan Kebudayaan, 11(01): 37-46.

Cahyani A. 2020. Motivasi Belajar Siswa SMA pada Pembelajaran Daring di Masa Pandemi Covid-19, IQ (Ilmu Alqur'an): Jurnal Pendidikan Islam, 3(01): 123-140.

Faznur LS. 2020. Analisis Kesulitan Siswa dalam Menyelesaikan Soal Cerita Matematika Materi Bilangan Bulat dalam Pembelajaran Daring. Prosiding Seminar Nasional Penelitian LPPM UMJ, pp. 1-7.

Hadiprasetyo K, Exacta AP, Maharani A. 2020. Matematika Dengan Pembelajaran Dalam Jaringan ( Daring ) Selama Masa Darurat Covid-19 Pada Siswa Kelas VIII SMP Negeri 2 Ngadirojo Tahun Ajaran 2019/2020. Jurnal Pendidikan, Sains Sosial dan Agama, VI(2): 6-12. 
Loviana S, Baskara WN. 2019. Dampak Pandemi Covid-19 Pada Kesiapan Pembelajaran Tadris Matematika IAIN Metro Lampung. Epsilon, 2(1): 61-70.

Menheere A, Hooge EH. 2016. Parental involvement in children' $\mathrm{s}$ education : A review study about the effect of parental involvement on children' $\mathrm{s}$ school education with a focus on the position of illiterate parents. Journal of the European Teacher Education Network JETEN, 6.

Mustakim. 2020. The Effectiveness of ELearning Using Online Media During The Covid-19 Pandemic In Mathematics. Al asma: Journal of Islamic Education, 2(1): 1-12.

Trisnawati W. 2021. Pendidikan Anak dalam Keluarga Era Covid-19. Jurnal Obsesi : Jurnal Pendidikan Anak Usia Dini, 5(1): 823-831.

Winarti P. 2021. Analisis Kesulitan Belajar Mahasiswa dalam Perkuliahan Konsep Dasar IPA Fisika Secara Daring di Masa Pandemi Covid-19', Jurnal Komunikasi Pendidikan, 5(1): 93-107.

Yulia IB. Putra A. 2020. Kesulitan Siswa Dalam Pembelajaran Matematika Secara Daring. Refleksi Pembelajaran Inovatif, 2(2): 327-335.

Zamista AA. 2020. Student Perception Of Calculus During Online Learning', Jurnal THEOREMS, 5(1): 41-48. 